\title{
GROUPS OF METEORITES AND METEORITE-DROPPING FIREBALLS IN ASTEROIDAL ORBITS
}

\author{
Yu. M. Gorbanev ${ }^{1}$ (D), N. A. Konovalova ${ }^{2}$ (D), N. Kh. Davruqov ${ }^{2}$ (D) \\ ${ }^{1}$ Astronomical Observatory of Odesa National University, \\ 2, Dvoryanska St., Odesa, UA-65082, Ukraine, \\ e-mail: skydust@ukr.net \\ ${ }^{2}$ Institute of Astrophysics of the National Academy of Sciences of Tajikistan, \\ 22, Bukhoro St., Dushanbe, 734042, Tajikistan
}

(Received 10 June 2021; in final form 01 November 2021; accepted 25 November 2021; published online 17 December 2021)

\begin{abstract}
This paper presents the results of a study of the existence of nine near-Earth meteorite-producing groups in asteroidal orbits, containing sporadic fireballs from the IAU MDC-2007 database, sporadic meteors from the SonotaCo database, meteorites - namely, L5, L6 and H4-H6 ordinary chondrites and an ureilite, for which atmospheric and orbital parameters are known from instrumental observations. Orbits of the selected members of meteorite-producing groups were classified as asteroid orbits according to the Tisserand parameter $T_{j}>3.1$.

Dynamic links between the members of the identified meteorite-producing groups and instrumentally observed known meteorites which were taken as a reference for the search of potential group members were tested using orbital similarity criteria, in particular the Drummond criterion $-D_{\mathrm{D}}$ and the Southworth and Hawkins criterion $-D_{\mathrm{SH}}$. As a result, several meteorite-dropping sporadic fireballs and small meteors, whose orbits are similar to the asteroid orbits of nine known meteorites, were detected and reckoned as possible members of meteorite-producing groups.

Key words: meteorite-producing group, meteor, fireball, meteorite, ordinary chondrite, Earthcrossing orbit.
\end{abstract}

DOI: https://doi.org/10.30970/jps.25.4902

\section{INTRODUCTION}

The notion that meteoroid streams could originate from asteroids was suggested by Hoffmeister [1] and Fesenkov [2]. Halliday et al. [3], having analysed the fireball data from the Meteorite Observation and Recovery Project (MORP) and the Prairie Network (PN), inferred the asteroidal origin of some fireball streams. The authors suggested that four possible meteorite-producing groups exist, among which group 1 included the Innisfree meteorite. Shestaka [4] examined a stream of meteorite-producing bodies, which produced the Innisfree and Ridgedale fireballs, and found out that the investigated stream was also related to nine small meteor streams, several asteroids and 12 fireballs. Greenberg and Chapman [5] reckoned that meteorites might be pieces of large Main-belt asteroids, derived primarily from craters of asteroids rather than disruptive fragmentation of parent bodies. Jopek and Williams [6] considered the possibility that a meteoroid stream of asteroidal origin could have formed through the ejection of fragments from an asteroid due to its collision with another body (an impact as the formation mechanism). In such a case, a portion of the fragmented parent body in the form of small particles and bigger fragments, such as cobbles and pebbles, survives as debris in its orbit. The authors have suggested that a collision will only produce a meteoroid stream if it involves relatively large bodies, with the asteroid-impactor being several tens of metres in diameter. Asteroid Vesta with its fragments expelled in the collision with the impactor and subsequently found on
Earth as meteorites - vestoids, can serve as an example of the formation of meteorites associated with impact events [7].

Spurny et al. [8] supposed the existence of a meteor stream, which might be produced by tidal disruption of a compositionally heterogeneous, rubble-pile asteroid. The evidence of high macroporosities in the interiors of some asteroids, for instance, (253) Mathilde, (1620) Geographos and (216) Kleopatra, as well as close-up images of the surface of asteroid (25143) Itokawa [9], suggest that a considerable portion of asteroids may have surface cracks (or fractures) and a rubble-pile structure. Such aggregates are only held together by a relatively weak gravity and may eventually break apart. The Near-Earth Asteroid 2008 TC3 that entered Earth's atmosphere on 07 October 2008 and broke apart into numerous meteorite fragments (overall some 650 fragments), collectively named the Almahata Sitta meteorite, is a comprehensive case study of such an asteroid of low mechanical strength. A study of mineralogical make-up of the found meteorite fragments has shown that asteroid 2008 TC3 contained meteorites of different types, including $H, L$ and $E$ chondrites and ureilites. The density measurements of the Almahata Sitta ureilites yielded a bulk density of $\sim 3.1 \mathrm{~g} / \mathrm{cm}^{3}$. Based on the study of the recovered meteorites, as well as observations of the atmospheric entry of asteroid 2008 TC3, the authors [10] suggested that asteroid 2008 TC3 could have formed as a result of low-velocity collisions between asteroid fragments of very different mineralogies. Therefore, asteroid 2008 TC3 was compositionally 
heterogeneous and had low mechanical strength and significant macroporosity, which lowered the asteroid's bulk density compared to that of the found Almahata Sitta meteorites.

The fact that asteroids can indeed eject dust (the so-called "dusty asteroids") was proved by the Lincoln Near-Earth Asteroid Research project (LINEAR) image of comet-like asteroid P/2010 A2 with a dust tail, formed in a collision between two asteroids that had occurred in February-March 2009 [11]. Williams and Wu [12] claimed that meteoroid streams formed through the dust ejection from an asteroidal body would contain far less mass and be far more diffuse than those of cometary origin. In that case, the spatial density of a meteoroid stream (group) of asteroidal origin should be lower while its meteor activity should differ from the activity of major meteor streams of cometary origin.

Though the probability of a collision with an Earthcrossing asteroid is statistically lower, such an impact will have calamitous consequences for our planet. A collision with a large $(10 \mathrm{~km})$ or medium-sized $(300 \mathrm{~m})$ asteroid is a low-probability event; however, it should not be neglected. Moreover, collisions with smaller objects, ranging in diameter from 10 to $100 \mathrm{~m}$, are expected to occur more frequently, thus posing proportional hazards to the environment and human life on Earth. As the problem of asteroid impact hazard to Earth's biosphere has gained increasing attention in recent years, the international project "Asteroid and Comet Hazard (ACO)" was launched. This project is focused on systematic monitoring of the sky, aimed primarily at detecting near-Earth asteroids whose orbits are similar to Earth-crossing orbits of meteoroid streams, especially short-period ones, which are close to the ecliptic and may pose an impact hazard to Earth.

\section{METHOD FOR DETECTING METEORITE-PRODUCING GROUPS}

Annual activity of 2,373 bright shower and sporadic fireballs, observed from across Canada and documented in the Millman Fireball Archive, was studied in [13]. From the resulting solar-longitude distribution of the cumulative number of fireballs representing an annual fireball activity profile, the peaks in the activity of fireballs from known meteor showers were identified. The peaks in the activity profile of fireballs from four meteorite-producing groups which could be related to meteor streams of asteroidal origin were identified as well. In the study [14], the authors analysed data on the time of observation of superfireballs and meteorite falls in Spain, based on the reports in newspapers collected for the period covering the last 150 years. The analysis revealed statistically significant peaks corresponding to stronger fireball activity for some periods of the year, which was not associated with known meteor streams.

The study [15] yielded histograms of the annual activity of sporadic bright fireballs, meteors and meteorites, which were constructed on the basis of data adopted from two meteor databases [16,17]. Six major (Maj) and two minor (Min) peaks in the activity of the investigated bodies, which were not connected with the dates of peak activity of known meteor showers, were identified from the plotted histograms. All data on the detected periods of the observed activity of sporadic fireballs, meteors, and meteorites laid the groundwork for studying the issue of clustering in the near-Earth space of the sporadic meteorite-producing meteoroids. Data on atmospheric paths, radiants, and heliocentric orbits of 24 known meteorites instrumentally observed in different years have been published in scientific journals to date. Among these 24 Earth-crossing orbits for known meteorites, four orbits of CI and CM carbonaceous chondrites and six orbits of $L 3.5$ and $H 5$ ordinary chondrites are Jupiter-family comet-like orbits, while 14 orbits of $L 5$, $L 6, H 4-H 6$ chondrites and an ureilite are recognised as asteroidal.

Using meteor databases, we carried out a search for fireballs and meteors with orbits similar to those of the 14 meteorites with Earth-crossing asteroidal orbits known from instrumental observations. We used the following method for detecting groups of meteorites and fireballs in asteroidal orbits: the data on a meteorite known from instrumental observations - in particular, its orbital elements, radiant co-ordinates, and the date of observation - were used as a reference for the search for members of the relevant group of meteorite-producing meteoroids. The selection of meteorite-dropping fireballs and meteors as members of a specific group was performed by cluster analysis of respective data on the meteorite and potential members of the group; in so doing, meteoroids in orbits proven to be similar by the specified orbital similarity criteria, such as the Drummond criterion, $D_{\mathrm{D}}$, [18] and the Southworth and Hawkins criterion, $D_{\mathrm{SH}}$, [19] were only selected. The search among 14 known meteorites in Earth-crossing asteroidal orbits yielded groups of meteorite-producing meteoroids linked to nine of the known meteorites, namely Innisfree, Novato, Villalbeto de la Pena, Lost City, Križevci, St. Robert, Jesenice, Grimsby, and Almahata Sitta.

\section{GROUPS OF METEORITE-DROPPING FIREBALLS IN EARTH-CROSSING ASTEROIDAL ORBITS}

In the present study, we investigated the possibility of the existence of meteorite-producing groups in nearEarth asteroidal orbits, consisting of sporadic meteoroids, meteorite-dropping fireballs, and instrumentally observed meteorites. The selection of members of the groups was carried out as follows: sporadic meteoritedropping fireballs, which could survive the flight through Earth's atmosphere with a non-zero terminal mass, were selected from the IAU MDC-2007 database [16], and sporadic meteors - from the SonotaCo database [17]. As a group-membership criterion to be met for the selection of meteorite-producing sporadic fireballs, meteoroids, and meteorites, we used the similarity of the orbits of 
a group's members to the orbit of a meteorite, known from instrumental observations, that fell within the time span of the observed occurrence of fireballs from the group and that was taken as a reference for the search for potential group members. The similarity between the orbits was tested applying two known criteria, used as a quantitative measure of the distance between the orbits, namely the Drummond $D_{\mathrm{D}}$ criterion [18] and the Southworth-Hawkins $D_{\mathrm{SH}}$ criterion [19]. The following threshold values of the orbital similarity criteria were used for selecting fireballs into the groups: $D_{\mathrm{D}} \leq 0.12$ and $D_{\mathrm{SH}} \leq 0.25$. Based on the heliocentric orbits, the selected sporadic fireballs were divided into cometary and asteroidal according to the Tisserand invariant $T_{\mathrm{J}}$ [20], defined by the following equation (1):

$$
T_{\mathrm{J}}=\frac{a_{\mathrm{J}}}{a}+2 \cos i\left(\frac{a_{\mathrm{J}}}{a}\left(1-e^{2}\right)\right)^{0.5}
$$

where $a$ and $a_{\mathrm{J}}$ are the semi-major axes of the fireball and Jupiter orbits, respectively, $e$ and $i$ are the eccentricity and inclination of the fireball. For cometary orbits, the Tisserand invariant is $T_{\mathrm{J}} \leq 3.1$ and for the asteroidal orbits, $T_{\mathrm{J}}>3.1$.

The search, based on the orbital similarity, duration of the observed activity (1-1.5 months), and radiant positions $\Delta \alpha_{\mathrm{R}}<35^{\circ}, \Delta \delta_{\mathrm{R}}<20^{\circ}$ of meteorite-dropping fireballs and meteors, selected from the meteor databases IAU MDC and SonotaCo, resulted in the detection of associated groups of meteorite-dropping meteoroids for 9 of the 14 meteorites of asteroidal origin with observationally known atmospheric and orbital parameters. Details about the nine detected meteorite-producing groups are listed in the Table below, providing the following data for each of the groups: a meteorite's name; year, month and date of observations; radiant co-ordinates the right ascension $\alpha_{\mathrm{R}}$ and declination $\delta_{\mathrm{R}}$; the entry (pre-atmospheric) velocity $V_{\infty}$; orbital elements, including the perihelion $q$, semi-major axis $a$, orbital eccentricity $e$ and inclination $i$, the argument of perihelion $\omega$, the longitude of the ascending node $\Omega$; and in the last two collums, the orbital similarity criteria $D_{\mathrm{D}}$ and $D_{\mathrm{SH}}$. For this group the bottom line gives the parameters of the mean orbit (Mean), for which the number of meteoritedropping fireballs that are members of the respective group is included in round brackets.

\begin{tabular}{|c|c|c|c|c|c|c|c|c|c|c|c|c|c|c|}
\hline Name & Year & $\mathrm{M}$ & $\mathrm{D}$ & $\alpha_{\mathrm{R}} \operatorname{deg}$ & $\delta_{\mathrm{R}} \operatorname{deg}$ & $V_{\infty} \mathrm{km} / \mathrm{s}$ & $q \mathrm{AU}$ & $a \mathrm{AU}$ & $e$ & $i \mathrm{deg}$ & $\omega \operatorname{deg}$ & $\Omega \operatorname{deg}$ & $D_{\mathrm{D}}$ & $D_{\mathrm{SH}}$ \\
\hline Mean (14) & - & 02 & 09 & 41.0 & 54.0 & 13.7 & 0.990 & 1.868 & 0.470 & 8.0 & 185.0 & 319.0 & 0.00 & 0.00 \\
\hline Innisfree & 1977 & 02 & 06 & 6.7 & 66.2 & 14.5 & 0.986 & 1.872 & 0.473 & 12.0 & 178.0 & 317.0 & 0.03 & 0.10 \\
\hline Mean (11) & - & 04 & 01 & 139.5 & 51.8 & 13.9 & 0.977 & 1.838 & 0.456 & 8.4 & 192.7 & 21.8 & 0.00 & 0.00 \\
\hline Jesenice & 2009 & 04 & 09 & 159.9 & 58.7 & 13.8 & 0.996 & 1.750 & 0.431 & 9.6 & 190.5 & 19.2 & 0.03 & 0.05 \\
\hline Mean (12) & - & 10 & 01 & 289.8 & -26.1 & 13.8 & 0.982 & 2.132 & 0.534 & 2.7 & 314.6 & 21.4 & 0.00 & 0.00 \\
\hline Novato & 2012 & 10 & 18 & 268.1 & -48.9 & 13.7 & 0.988 & 2.090 & 0.526 & 5.5 & 347.4 & 24.9 & 0.11 & 0.33 \\
\hline Mean (7) & - & 12 & 27 & 321.1 & 4.2 & 15.9 & 0.921 & 2.379 & 0.607 & 5.3 & 142.3 & 278.1 & 0.00 & 0.00 \\
\hline Villalbeto & 2004 & 01 & 04 & 311.4 & -18.0 & 16.9 & 0.860 & 2.300 & 0.630 & 0.0 & 132.3 & 283.7 & 0.05 & 0.12 \\
\hline Mean (9) & - & 01 & 01 & 285.5 & 24.7 & 14.3 & 0.953 & 1.847 & 0.479 & 7.4 & 165.0 & 282.6 & 0.00 & 0.00 \\
\hline Lost City & 1970 & 01 & 04 & 315.0 & 39.1 & 14.2 & 0.967 & 1.660 & 0.417 & 12.0 & 161.0 & 283.8 & 0.06 & 0.11 \\
\hline Mean (19) & - & 02 & 21 & 137.0 & 17.8 & 18.9 & 0.783 & 2.075 & 0.614 & 3.4 & 242.2 & 328.6 & 0.00 & 0.00 \\
\hline Križevci & 2011 & 02 & 04 & 131.2 & 19.5 & 18.2 & 0.740 & 1.544 & 0.521 & 0.6 & 254.4 & 315.6 & 0.09 & 0.11 \\
\hline Mean (16) & - & 06 & 02 & 187.9 & 12.0 & 13.3 & 0.994 & 2.085 & 0.517 & 4.2 & 191.5 & 71.6 & 0.00 & 0.00 \\
\hline St. Robert & 1994 & 06 & 15 & 176.0 & 6.0 & 13.0 & 1.016 & 1.900 & 0.480 & 0.7 & 179.0 & 83.7 & 0.04 & 0.08 \\
\hline Mean (8) & - & 09 & 17 & 251.9 & 49.8 & 19.4 & 0.997 & 2.290 & 0.554 & 24.4 & 171.5 & 175.7 & 0.00 & 0.00 \\
\hline Grimsby & 2009 & 09 & 26 & 242.6 & 55.0 & 20.9 & 0.982 & 2.040 & 0.518 & 28.1 & 159.9 & 182.9 & 0.05 & 0.10 \\
\hline Mean (7) & - & 09 & 23 & 339.5 & 13.9 & 14.4 & 0.888 & 1.413 & 0.312 & 6.1 & 235.4 & 187.4 & 0.00 & 0.00 \\
\hline Almahata Sitta & 2008 & 10 & 07 & 348.1 & 7.6 & 12.4 & 0.900 & 1.308 & 0.312 & 2.5 & 234.4 & 194.1 & 0.02 & 0.07 \\
\hline
\end{tabular}

Table 1. The groups of meteorite-dropping fireballs and known meteorites with similar asteroidal orbits (at epoch 2000.0) 

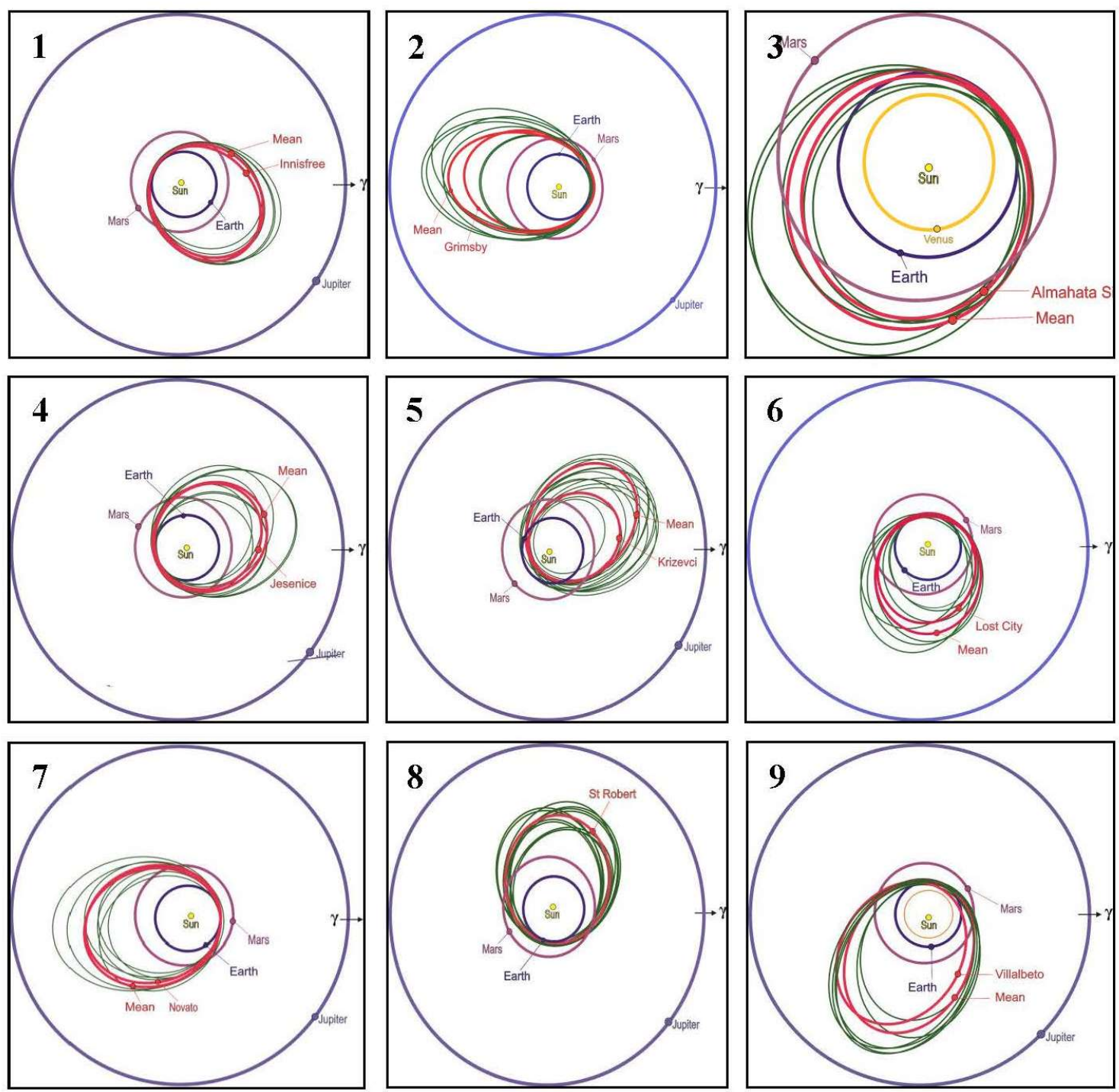

Fig. 1. Orbits of nine meteorite-producing groups of meteorite-dropping fireballs and known meteorites in asteroidal orbits

Orbits of nine meteorite-producing groups are illustrated in Figure 1, which depicts, in particular, a meteorite's instrumentally determined orbit, the mean orbit (Mean) of the group and also orbits of meteoritedropping fireballs belonging to the respective group: $1-$ group of meteorite Innisfree; 2 - group of meteorite Grimsby; 3 - group of meteorite Almahata Sitta; 4 - group of meteorite Jesenice; 5 - group of meteorite Križevci; 6 - group of meteorite Lost City; 7 - group of meteorite Novato; 8 - group of meteorite St. Robert; 9 - group of meteorite Villalbeto.

\section{CONCLUSIONS}

In the present study, the search among objects, selected from the IAU MDC-2007 and the SonotaCo Network databases by the orbital similarity criteria, duration of the observed activity, and radiant coordinates, has yielded nine meteorite-producing groups of sporadic fireballs and meteors in asteroidal orbits, which include nine known, instrumentally observed meteorites - namely, L5, L6, H4- $H 6$ ordinary chondrites, and an ureilite. The search in the meteor databases for plausible meteorite-producing groups of four meteorites, namely the Peekskill, Moravka, Bunburra Rockhole and Buzzard Coulee meteorites, with instrumentally determined atmospheric paths and orbital parameters has yielded no results with regard to meteorite-producing groups that could be associated with these meteorites as per available meteor and fireball databases. According to one of possible scenarios, the similarity of orbits of the group members, that is, members of a genetically associated group, could have formed through the disruptive fragmentation of the parent body (NEA), and thus the fragments became a group of genetically related members. Porubcan et al. [21] pointed out that they only included as real genetically related pairs of meteoroids and plausible parent NEAs those for which the orbital evolution was proven to be similar over 5,000 years. In an alternative scenario, such a relationship between meteoroids within a certain group could 
have formed occasionally. Both scenarios do not rule out possible existence of some near-Earth meteoriteproducing meteoroids, which being related to the investigated groups have not yet been detected through optical observations. The feasibility of identifying a plausible parent body related to a specific group and determining the age of a group of genetically associated meteoroids is crucial for establishing relationships between groups of meteorite-producing meteoroids and their parents, that is, comets or asteroids, and also for studying mechanisms of formation of the investigated meteorite groups. Within the framework of the project addressing the problem of asteroid impact hazard to Earth's environment and biosphere in particular, it is essential to systematically monitor the sky in the field of radiant specified for meteorite-producing groups during periods of their activity. Ultimately, it is extremely important to early detect potentially hazardous meteorite-producing meteoroids in the near-Earth space well before they enter Earth's atmosphere.
[1] W. Malsch, C. Hoffmeister, Astron. Nachr. 262, 45 (1937); https://doi.org/10.1002/asna. 19372620305.

[2] V. G. Fesenkov, Astron. Zh. 35, 3 (1958).

[3] I. Halliday, A. T. Blackwell, A. A. Griffin, Meteoritics 25, 93 (1990); https://doi.org/10.1111/j.1945-5100.19 90.tb00981.x.

[4] I. S. Shestaka, Astronom. Vestn. 28, 94 (1994).

[5] R. Greenberg, C. R. Chapman, Icarus 57, 267 (1984); https://doi.org/10.1016/0019-1035(84) 90072-1.

[6] T. J. Jopek, I. P. Williams, Mon. Not. R. Astron. Soc. 430, 2377 (2013); https://doi.org/10.1093/mnras/st t057.

[7] C. M. Pieters et al., in Proceedings of the International Astronomical Union 229, 273 (2006); https: //doi.org/ 10.1017/S1743921305006794.

[8] P. Spurny, J. Olberst, D. Heinlein, Nature 423, 151 (2003); https://doi.org/10.1038/nature01592.

[9] A. Fujiwara et al., Science 312, 1330 (2006); https:// doi.org/10.1126/science. 1125841.

[10] T. Kohout et al., Icarus 212, 697 (2011); https://doi. org/10.1016/j.icarus. 2011.01.037.

[11] D. Jewitt, Astron. J. 143, 66 (2012); https://doi.org/ $10.1088 / 0004-6256 / 143 / 3 / 66$.
[12] I. P. Williams, Z. Wu, Mon. Not. R. Astron. Soc. 262 231 (1993); https://doi.org/10.1093/mnras/262.1. 231.

[13] M. Beech, WGN J. Int. Meteor Org. 34, 104 (2006).

[14] S. Zamora, F. Ocaña, A. Sánchez de Miguel, M. Mole, in Proceedings of the International Meteor Conference IMC 2015 (Mistelbach, Austria, 2015), p. 187.

[15] N. A. Konovalova, Yu. M. Gorbanev, N. Kh. Davruqov, Odessa Astron. Publ. 31, 174 (2018); https://doi.org/ 10.18524/1810-4215.2018.31.145083.

[16] https://www .astro.sk/iaumdcDB/.

[17] SonotaCo database, http://sonotaco.jp/doc/SNM/in dex.html.

[18] J. D. Drummond, Icarus 45, 545 (1981); https://doi. org/10.1016/0019-1035 (81) 90020-8.

[19] R. B. Southworth, G. S. Hawkins, Smiths. Contrib. Astrophys. 7, 261 (1963).

[20] L. Kresak, Bull. Astron. Inst. Czech. 20, 177 (1969).

[21] V. Porubčan, I. P. Williams, L. Kornoš, Earth Moon Planets 95, 697 (2004); https://doi.org/10.1007/s1 1038-005-2243-5.

\title{
ГРУПИ МЕТЕОРИТІВ ТА МЕТЕРОРИТОУТВОРЮВАЛЬНИХ БОЛІДІВ НА АСТЕРОїДНИХ ОРБІТАХ
}

\author{
Ю. М. Горбаньов ${ }^{1}$, Н. А. Коновалова ${ }^{2}$, Н. Х. Давруков ${ }^{2}$ \\ ${ }^{1}$ НДI "Астрономічна обсерваторіл" Одесъкого начіоналъного університету, \\ вул. Дворлнсъка, 2, Украӥна, Одеса, 65082, Украӥна, skydust@ukr.net \\ 2 Iнститут астрофізики Націоналъноӥ Академіӥ наук Таджикистану, \\ вул. Бухоро, 22, м. Душанбе, 734042, Республіка Таджикистан
}

У статті подано результати аналізу наявності в навколоземному просторі дев'яти метеоритоутворювальних груп на астероїдних орбітах, що включають спорадичні боліди з бази метеорних даних IAU MDC 2007, спорадичні метеори з бази даних SonotaCo і метеорити - ordinary chondrites type L5, L6, H4-H6 та Ureilite, з відомими, за інструментальними спостереженнями, атмосферними й орбітальними параметрами. Належність орбіт відібраних членів груп до астероїдного типу встановлено за значенням параметра Тіссерана $T_{\mathrm{J}}>3.1$. Динамічний зв'язок членів виявлених метеоритоутво-

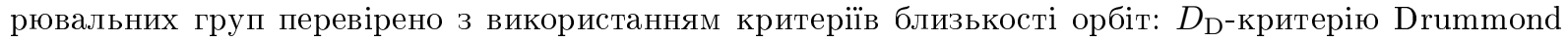
та $D_{\mathrm{SH}}$-критерію Sauthworth і Hawkins. У результаті кілька спорадичних метеоритоутворювальних болідів та слабких метеорів, орбіти яких на цей момент подібні до астероїдних орбіт дев'яти відомих метеоритів: Innisfree, Jesenice, Novato, Villalbeto de la Pena, Lost City, Križevci, St. Robert, Grimsby and Almahata Sitta, були виявлені як члени метеоритоутворювальних груп.

Група метеоритоутворювальних болідів та метеорів з астероїдними орбітами могла сформуватися в минулому від руйнування ймовірного батьківського тіла - навколоземного астероїда (NEA). 
У такому разі можна припускати, що група містить генетично пов'язані члени групи - метеоритоутворювальні боліди та метеори. Орбіти членів груп повинні були зберігати схожість між собою та орбітою батьківського астероїда протягом 5000-літнього періоду в минулому. Не виключається також можливість перебування на навколоземних орбітах випадково сформованих груп метеоритоутворювальних метеороїдів.

Можливість ідентифікувати ймовірне батьківське тіло з групою і визначити вік групи генетично пов'язаних метеороїдів на основі аналізу еволюції орбіт членів групи має велике значення для встановлення взаємозв'язків між групами метеоритоутворювальних метеороїдів та їхніми батьківськими тілами - навколоземними кометами або астероїдами.

Розгляд можливих механізмів утворення досліджуваних метеоритних груп, у яких можуть міститися великі фрагменти від руйнування батьківських тіл, становить інтерес з огляду на астероїдну небезпеку для навколишнього середовища й біосфери Землі.

Ключові слова: метеоритоутворвальна група, метеор, болід, метеорит, звичайний хондрит, астероїд, землеперетинальна орбіта. 